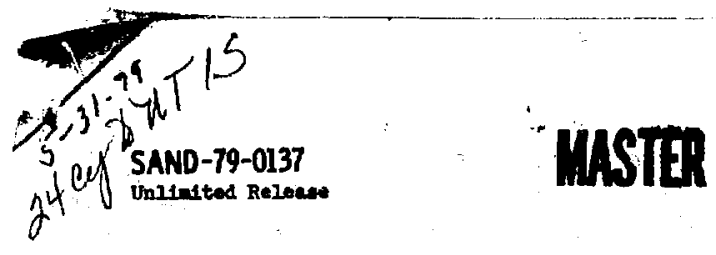

\title{
CONSTITUTIVE MODELS APPLIED IN THE ANALYSIS OF CREEP OF ROCK SALT
}


SALT-79-0137

Unlimited Relesse

Printed April 1979

CONSTIIUITVE MODELS APPIIED IN THE ANAIYSIS

OF CREEP OF ROCK SAIT

Pavl R. Dawson

Computational Fhyales \& Mechanics Division I - 5531

Sandla Iaboratortes, Albuquerque, New Mexico 87185

ABSTRACT

Constitutive equations for the creep of rock salt that bave been utilized in the analyses of salt deformations are sumarized. Primary creep, secondary creep, and elastoviscoplastic models are discussed. The strains predicted by several of the primary creep constitutive models are compared for Identical conditions of deviatoric stress and temperature. Steady-state creep rates are compared under identical conditions of deviatoric atress and temperature for the secondary creep equations.

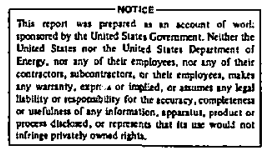


I. INTRODUCTION. ....................... 5

II. CREEP, CONSTITUTIVE MODELS FOR CREEP, AID ASSOCIATED MIMERICAL

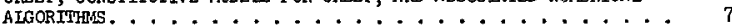

III. EXFERIMENTAL INVESTIGATIONS AND REVIEW ARTICLES . . . . . . 13

IV. SFECTFTC CREEP MODELS ARD APPLICATIONS. . . . . . . . . . . 15

IV.I Primary Creep Constitutive Equations and Applications . . . 15

TV.2 Seccndary Creep Constitutive Equations and Applications . . 22

IV.3 Elastoviscoplas ic Constitutive Equations and

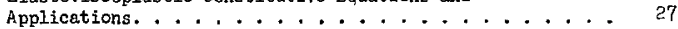

IV.4 Creep Rupture Models. .............. 2 ?

v. SUMMARY AND ASSESSLENT. .................. 31

APPENDIX A. STRESS AND STRAIN MEASURES ......... 33

I. PRIMARY CREE CONSTITUTIVE EQUATIONS. ............ 4 . .

II. PRIMARY CREEP STRAIIS ................ 4 . .

III. SECONDARY CREEP CONSTITUTIVE FQUATIONS. . . . . . . . . . i3

TV. SECONDARY CREEP RATES . . . . . . . . . . . $\mathrm{H}_{\mathrm{H}}$ 


\section{INTRODUCTION}

The creep of rock selt has been studied by numerous investigators over the past two decades. Studies have encomparsed the behavior of both single crystal ard polycrystalline salt over a wide range of temperature ano stress environments. Constitutive models for salt that reflect the observed creep behavior have been formulated from the experimental data as part of many of these investigations.

The purposs of this report is to sumarize sone of the creep constitutive rouations that have been employed in the past and are currently being employed in the anglyses of the mechanical response if rock salt, No attempt will be made to maku comprehensive comparisons of the constitutive equations or to reach a final conclusion on which equation is best suited for WIPP analyses, Several review articles hove been published that discuss the creep experiments of various investigators from vhich the models are derived. This report does not attempt to reproduce those efforts, but rather applies the general background given in the review articles to the sumary of creep equations that have been reportal.

This report presents a brief general discussion of both the constitutive models for creep and the numerical algorithms associated with solving these problems. Examples of the various types of creep models are discussed along with their application to geologic analyses. Finally, a brief assessment of creep models is presented. 
II. CREEP, CONSTITUTTVE MODEIS FOR CREEP, AND ASSOC IATED NUMERICAL AIGORITHAE

Creep can be defined in terms of the time dependent deformation of $a$ material subjected to a constant stress state. Laboratory experiments are typically idealizr:; Into three stages of creep deformation for a specjmen subjected to constant stress for long periods of tine. These are describet as (1) primary cresp, demonstrating derreasing deformation rates, (2) secondary ereep, demonstrating constant deformatirn rat. s, and (3) rertiary creep, exhibiting inexofe ing rinformation rates and norma $11 y$ terminatires witi, fracture or instability.

Experiments on rock salt have produced deta that substantiate that all thrercrasp regimes car be obtained depending on the stress state and tomperatur.. Th: relative importance of each regime is controlied by the deformation michanisnr that are active under the imposed conditions of stress and temperature. Then deformating. mechanisms inc?ude defect-10ss flow, dislocation glide and climb, iffucicnol creep,

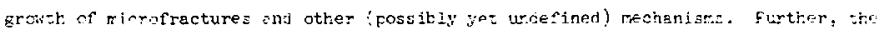

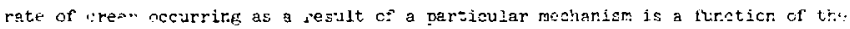
infosed environsental corditior.s.

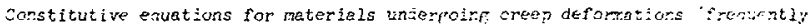

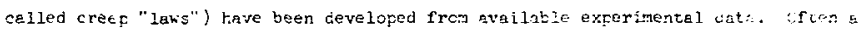

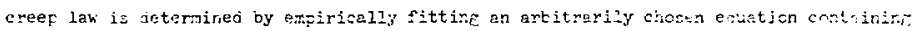
tha necessary independent varlaties. In other instances, the fora of the conetitutiv

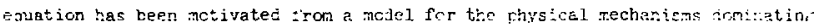
secondary creep. In this instance, the farameters mppearine ir the wations ar ceteminec such thet the equations can sporoximete she sate. Eguatins aspce inte:

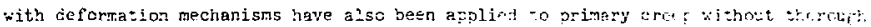
physical tustification.

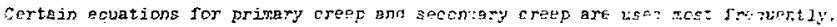
It will be helpful to review these equation: in fenral terma baforo a scuseini fpocirie cases. For primary creep, constitutive equations of the iorm

\footnotetext{
* Here the deformation rate refers to a tensor jefined in terms of simmeric portion. of the velocity gradient.
} 


$$
\dot{\varepsilon}=f(\tau \text { or } e) g(\theta) h(\sigma)
$$

have been rrequently used, where $\varepsilon 18$ the creep strain, $T$ is time, $n$ is the temperature, $\sigma$ is the stress, and $f, g$, and $h$ represent functions. Creep laws using Equation (1) assume that the effects of time, temperature, and stress on the induced creep straln rate are separable. Functionel foras of $g$ thet have been reported include power laws $\left(e^{\mathrm{n}}\right)$ and exponential law forns $(\exp (-Q / R F))$. The exponential forms are related to activation energies (Q) associetes with deformetion mechenisms, while the poier lavi forn is apparently strictly empirical. The use of time ( $)$ ) or strain (c) as the irdependent variable for $f$ leads to the time-hardening or strain-hardenir.B interpretations for the decreasing strain rate as a function of tine, cbsemed juring constant stress creep tests. Life fraction miles for the function $f$ have been proposed as an altemative to time and strain-hardening representations in which the proportion of total possible deformation that nas cccurred enters the constitutive madel in place of time or strain. The stress function h has most fuequently been expressed as a power law $\left(\sigma^{n}\right)$ to reflect the passible nonlinearity associated with the stress state.

The distinction between strain-hardening and time-hardening is important in applications that have changing stress and temperature fields. Strain-hardening laws normally require that as the stress state changes, and thus moves from one constant. stress and tenperature creep curve to another curve, the shirt occurs jecween points of enul total strain on the two constant stress curves. Time-hariening laws reauire that the change fror. one constant stress curve to another occurs between eque: tines on the two constant stress curves. These tho interpretations can give very different results. Life iraction rules represent a means of compronisins betreen time-harcening and strain-hardening by noving fror. one constant stmess curve to enother accorcing te eavel percentages of the total deforration that can be tolerated by the meterial. Tirehardening laws cre the simplest to irplement in a solution algorithe ard are prohebly the most comonly used. They are most successfuily applied when the probler. irvolves a stress state that is constent in time, but can prosuce very poer results if this is not the case. Time is not an intrinsic material property and, in genersl, shoula not appear explicitly in the constitutive model. 
Secondary creep (also salied steady-state creep) is cheracterlzed by consiant deformation rates under conditions of constant stress and temperature. Separanle constitutive equations of the form

$$
\dot{\varepsilon}=\mathbf{f}^{\prime}(\theta)_{\mathrm{g}}{ }^{\prime}(0)
$$

have been used to model creep within this regime. Weertman [1] has proposed that the functions $\mathrm{f}^{\prime}$ and $\mathrm{g}^{\prime}$ be defined as

$$
f^{\prime \prime}(\theta)=\frac{A \mu}{\partial} \exp \left(-\frac{\theta}{\mathrm{R} \theta}\right)
$$

and

$$
\mathrm{g}^{\prime}(\sigma)=\left(\frac{\sigma}{\mu}\right)^{n}
$$

where $\mu$ is the shear modulus, $Q$ is the activatinn energy, and $R$ is the universal bas constant. Hunerous investigators have found this law to be a good approximation for secondary crepp involving dislocetion climb (colyonization) at mojerates stres leve:s. It has also bren observed that lhe wmprature dependence or $\mu$ leads to the fact thet the cuentity $\frac{A \mu}{j}\left(\frac{1}{\mu}\right)^{n}$ is nearly constant. At higher stress levels, where slip occurs, the stress function is expressed as an exponentiel function such as $\sinh (\mathrm{B} a)$. It very low deformation rates and elevated temperature, where the diffusion limitine Nabarrnüierring [2i or Coble rej creep mechenisms dominste, a Linear dependerse between stress ard decormation rate is obtakisć.

Tertiary creep exhibits increasing deformation rates that lead to failura. zome work has been rone in developing constitutive models in tems of creep rupture theory that are appropriate for the terticiy creep regime. The onset of instability characterized by tertiary creep has been observed to be related to the totul strain. However, little has been done to express either the transition from socondary =0 tertiary creep or creep rates in the tertiary crecp range using constitutive entiaticrs for rock sait $[3]$.

The above primary creep and secondary areep models, Eajutions (1) and (2)) are geparable in their form. This Implies, for instance, that if two creep tests are performed at temperatures $5_{1}$ and $?_{2}$, with the stress state the seme in each test, the 
ratio of strein rates between these tests must equal the ratio of strain rates of a second set of two creep tests performed at $\theta_{1}$ and $\theta_{2}$ but at a different stress state. Currently, several efforts to develop constitutive nodels for the creep deformation of salt are being conducted. Some of the efforts have been motivated by the assumption that more than one mechanism is active for a particular combination of independent variables $[5,6,7]$. This assuraption has led to constitutive models having additive orimary or secondary creep functions and provides a means of heving multiple activation energies and stress nonlinearities. A second effort currently being developed involves construeting a detailed deformation mechanism map thet cefines the transition zones between dominant creep mechanisms [7]. This erfort provices a means of quantifying where a given mechenism dominates over other mechanisms, but alone does not fully account for more than one mechanism veing active at a particuler stress and temperature state.

Aralyses of creep deformations of selt have been provided in recent years by numerical methods using finite element or finite difference methods in the spece domain and various muerical technioues in the time domain. Some of the analyses use elastcplastic models to predict the stress state due to the appliec loacis. Criep cefcrmations are then predicted using the computed stress state in con unctior. with with creep law. Other anglyses are formulated from a creeping flow formulation in which the elastic response is neglected.

Elastoplastic formletions norrally assure ineer elastic behavior cor stress states 1 ying below the yield surface (typically a Nohr-Coulamb failure criterion is used). Once the stress reaches the yield surface, the material deforms inelastically and independently of time. The stress state resulting from the elastoplastic analyses is introduced into the creep law to predict the creep strain increment for a specified time inrrement. Some analyses have applied a yield surface concept to the oreep law in such a way that no creep deformations occur below a certain limiting stress. Creepirg viscols flow formlations heve also been epplied to the analysis of creep deformations. These formulations relate the applied stress field to the jeforration rates of the material using the creep law as the constitutive modei for a non- 
Nowtonian fluid. Wormally such formulations neglect the elastic portion of the deformation and, thus, apply to problems in which creep strain increments dominate over elastic strain increments for a given time increment. 
III. EYFERTMENTAL INIESTICATIONE AND FEVIEW ARTICLES

Nunerous investigators heve Derformed laboratory experients to necrst the That-

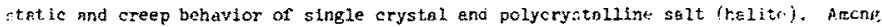

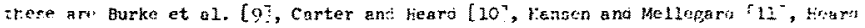
[12], Le conte [13], Lomenick [14], Nenze] et a1. [15], Nair r 16;, Poirir: [17j,

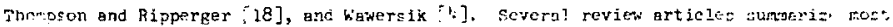
af la nvaliabie sata $L 19,21 .$.

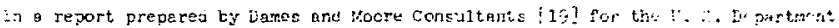

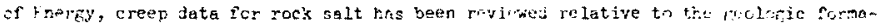

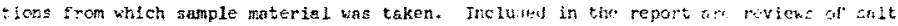

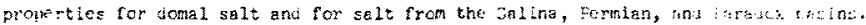
The report sumbrizes known values of density, water conront, permeatility, flati, ir:

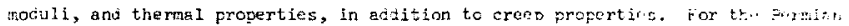

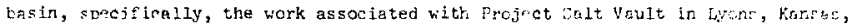

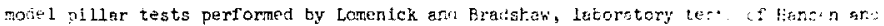

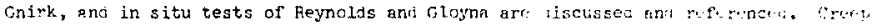

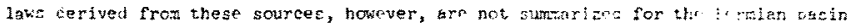

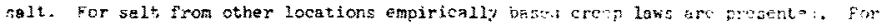

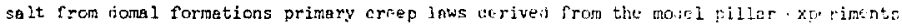

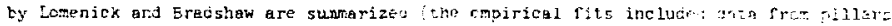

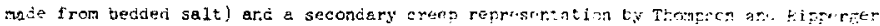

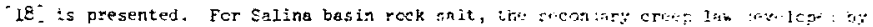
Soert $[2]^{-}$is aiven.

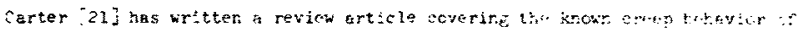

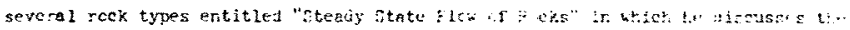

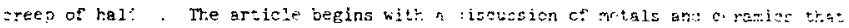

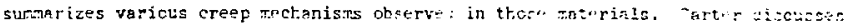

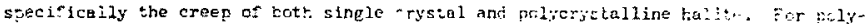

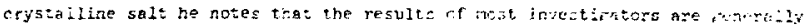
conslstent with sell other. He then concratrntes rin thr tejorte: data cf ling: 
because his data cover the broadest combined range of pressure, temperature, and strain-rate. Nabarro-Herring creep and dolocation glide and climb (polygonization) are diacussed tncluding the strain rates at which the transition from one creep mejhanlsm to another occurs. Applicationa center ercund activities of tectonic scalc sucis as diapirism, folding, and mantle convection.

Basr [22] has published a monograph on rock salt mechanics. This text contains discussions on the geology and physical properties of rock salts as well as nuxcerous references to in sttu convergence measurements in salt mines. Fanf calls attention to questionable assumptions made in formulating creep laws from laboratory data of creep rates. Baar's pereeption from mine boscrvations is that strain-lardening observed in the laboratory does not exist in situ.* Further, creep linits (1,e., stress levels below which creep will not occur) are either zero or nearly zero for rock salt. Eaar emphasizes that strain-hardening models that increase the octahedral stress required to infitiete creep lead to unconservative designs.

Thoms and Martinez [23] have prepared a review of salt material properties as par:- of a project to store energy via compressed air 'n caverns within salt doses. This report is a general deseription of material tor for time-indepenoent plas*icity and creep of salt and the numerical methods for anal-'i salt ceformations using plasticity and creep models. The constitutive equations are ciscussed within the context of prizary, secondary, and tertiary creep without relating the creop to specific deformation mechanisms. Much of this report emphasizes the short term response following the opening of cavitles using ausi-static test results to evaluate parameters necessary for time-independent plasticity models.

The reviews of selt properties by Dames and Moore Consultants, Carter, Baur, and Thoms and Martinez provide a good sunmary of the work performed over the past ten years. The references cited in the reviews are quite extensive.

\footnotetext{
Ft appears that Baar means that salt will reach the secondary regire fickly after being loaded and thus will demonstrate constant strair rates for constant stress conditions. The primary creep regime is embodied in what Bear terms stress rolief creep.
} 


\section{TV. SFECIFIC CREEP MCDEIS ARD APPLICATIUNS}

In many Instances, the laboratory data from cbserved creep behavfor of rock salt, have been utilized to evaluate parameters for primary and secondary creep models. These creep models have subsequently been applied in the analyses of the areep of room and pillar mine gemetries and other applications. Creep laws have also been generated by using in sitv experimental data in confunction with numerical solutions to obtain creep paraneters that lead to the best match of predicted and meastirer deformations. We vill consider creep equations obtained in both ways. Prinery creep laks are discussed first, followed by secondary ereep mod?ls. Elastoviscoplastic and criep rupture models for rock salt behavior are stummarized.

\section{IV.1 Primary Creep Constitutive Equations and Applications}

Meclain eno Surfield [24] have analyzed plller ifforitetions that were measurrt during Projpct. Salt. Vault. They uset a prinary creep ecuation determined from the model pil:,, t,ests of Lomenick [14] using salt principaliy from Lyons, Kansos. The creep constitutive equation meported is

$$
\varepsilon=1.3 \times 10^{-37} \nabla^{9.5} \tau^{0.3} \sigma^{3.0}
$$

where $c$ is the strain, $\partial$ is the aversge pillar temperature ( $K)$, - is the time (hours) and $\sigma$ is the average pillar vertical stress (psi). In orcer to genera: $z e$ zhis iaw for conditions of varying stress and temperature, Acclais. and starfield firsi expresced the differential strain as a function of the differential stress. This equation is then fntigraled with respect to time to obtain an expression for strain as a runction of time. Tiry next introduce a time scale shift sufgested by Leaderman [25". to gceount for changing temperature. The generalized constitutiva ejuation for creep under conations of varying terperature and stress was then applied in the analysis of pillar jeforrations measured during Procitat Salt Vault. ilcclain and Etarfieli reportis, however, that the measured deformations soukd he better simulated by modifying the original constitutive model obtained fram lomenick's date to be

$$
\varepsilon=6.5 \times 10^{-37} \therefore .5,0.37 s^{3.0}
$$


where variables have the same dimensions as presented before, coefficiente in this law were obtained by trial-and-error to provide the best match to measurid values. Compited deforrinifions (obtained with parameters determined by trial-and-error) have been conpared to measured values for a period of 1500 degs following excavat: $n$. Hardy and St. John [26] have extended the work of Mcclain and Starfield [24?, using the primary creep model reported by Mcclain an starfield as a beft fit to the Frofect Salt Vault in situ steasurements, and rean*, sh the plllar feformations

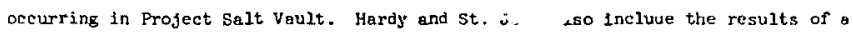
ihree-dicensionel therraceiastic repository simulation.

hahi, Maxwe11, and Hofwann [27! have reported numerical sloulations of projact Salt Veult pillar deformaticns. They lised two-dimensional, explicit, finstei:ifference method for the anelyses In conjunction with creep law paraneters reportad by Starfiele and McClam. Wahl, Maxwell, and Hofmam haye also modified the prinery creep law derived under conditions of constant atress and temperature tis gccout for changing stress and temperature fields. In their analyses, they simulated the effects of excavation sepuencing, but concluded that the sequencing had 1 ittic ifiest on deformation of the pillars, given that heating did not begin for approximately six months after excevation ended.

In another report by Maxwell, Waht, and Dial $\left\lceil 28^{*}\right.$, the elastic and creap responcr.; cup to stresses coused by thermel expansion ror a full scale repository have pern simulated. A prinary ereep law was biso used in these simulationo. Parameters ror the crecp law were determined from creep tests reported by Hansen and Vile LES: II ${ }^{-}$. The sreep equation used in the simulations was

$$
\dot{\varepsilon}_{\text {creep }}=6.0195 \times 10^{-43}\left[s^{3.0} \exp (-4100 / \epsilon)\right]^{\frac{1}{.1 .656}}\left[e_{\text {creep }}\right]^{-1.15}
$$

and

$$
\dot{\varepsilon}_{i j}=\xi_{\text {creep }} \frac{z_{1 j}}{s}
$$

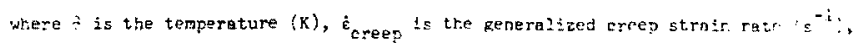
and $S$ is defined by 


$$
s=\sqrt{\frac{1}{6}\left[\left(\sigma_{x}-a_{y}\right)^{2}+\left(\sigma_{y}-\sigma_{z}\right)^{2}+\left(\sigma_{z}-\sigma_{x}\right)^{2}\right]+\sigma_{x y}^{2}+\sigma_{y z}^{2}+\sigma_{z x}^{2}} \quad(\text { Pa) }
$$

or $S=\sqrt{J_{2}}$ (where $J_{i c}$ is the second invariant of the stress tensor). A tromoimensionel, explict, flate-difierence computer code ves used in these analyses.

Ratigan and Callahan [29] have reported on a thermoviscoelastic simulation or pillir deformationa assoclated whh profect Salt Vault. The prinary ereep law utilized in their computations was detemined from a combination of data reportati by Bradshew and MeClain [24] and by Hansen [30], The creep law reported is

$$
c_{1 \mathrm{j}}=6.865 \times 10^{-15}\left(\frac{0}{295.5}\right)^{9.5} 0^{0.4} \mathrm{~J}_{2} \sigma_{1 j}^{\prime}
$$

Where - is the time $(s), 9 I \varepsilon$ the temperature $(K), J_{2}$ is the second irvarian: of the stress deviator $\left(\mathrm{psi}^{2}\right), \sigma_{i j}^{\prime}$ is the stress deviator tensor (Fsi), and $\varepsilon_{i j}$ is tre sirairi tensor. Ratigan and Callshon employed a finlte element cooe to perfort the pillgr simulations in which the creep strain rates have been computed from the stress fieid. This epproson uses a form of zoution (9) that had been differentiated with respect to tine.

Hansen [31,32] performed laboratory creep experiments on Jefferson Island salt. He performed a multiple regression analys is to detereine the paraneters appearing in an 1sothermel poier lan for primary creep. The creep ecuation is given as

$$
\varepsilon_{1}=i .18 \times 10^{-\hat{2} 3} T^{0.38_{(i s)}}{ }^{2.52}
$$

where $\epsilon_{I}$ is the axial strain, - is the time $(s)$, and to is the differential axibl stress (Fa), fanser a 350 discusses a creep 1 aw proposed by Fossura -33 in which the Trelastic strain-rate $(\dot{\varepsilon})$ is expressed as a function of the stress jeviator i $\left.{ }^{\prime}\right)$, second invariant of the stress deviator $\left(\mathrm{J}_{2}\right)$, and the inelastic generalized strein e. Specifically, this law is given as

$$
\dot{\epsilon}=2.99 \times 10^{-19}\left(\frac{\left(3 \mathrm{~J}_{2}\right)^{\frac{1}{2}}-68.1 \times 10^{7} e^{0.326}}{\left(3 \mathrm{~J}_{2}\right)^{0.286}}\right) \times \sigma^{\prime}
$$

where the dimension or $J_{2}$ and $\theta^{\prime}$ are in Pascals and the dlansion of $\dot{\varepsilon}$ is $s^{-1}$. Ttis law yiezds 


$$
\varepsilon=0 \text { as }\left(3 J_{2}\right)^{\frac{1}{2}}-68.1 \times 10^{7} \varepsilon^{0.326}=0 \text {. }
$$

Values of strain above 2.0 percent cause the strain rate to quickly approach zero, thus allowing the total strain to asymptotically approsch a predeterminea maximurs value. This maximam strain was evaluated from observation of laboratory creep tests. Hansen has enpirteally detemined primary creep laws for rock salt frem Lyonis, Kansas [30] and rock salt fron southeast New Mexico [11,34]. The creep laws reported for these salts are

$$
\begin{array}{lll}
\varepsilon_{1} & =7.2 \times 10^{-18} \tau^{0.4} \sigma^{3.7} \theta^{9.5} & \text { Lyons Salt } \\
\varepsilon_{1}=1.1 \times 10^{-35} \tau^{0.4656} \sigma^{2.475} \theta^{8.969} \mid & \text { Southeast in Salt } \\
\varepsilon_{1}=1.693 \times 10^{-39} \tau^{0.4808} \sigma^{2.676} \theta^{10.17} &
\end{array}
$$

where $T$ is the time ( $s$ ), $\sigma$ is the axial differential stress (psi), $\varepsilon_{1}$ is the axial strain, and 6 is the temperature $(K)$.

Russe1] [6] has investigated the possibility of using a combination af strainhardening function:s to model the primary creep regime and a Weertman secondery creep equation (Eauation (2)) to model the steady-state regime. He assumes that the transition from primary to secondary creep occurs at 10 percent strein. For the primery regime, Russell has performed a fit to constant strain-rate data of heart [12] using an empirically based equation of the form

$$
\dot{\varepsilon}^{-1}=\sum_{i=1}^{2} A_{1} \exp \left(-\lambda_{1} / e\right)
$$

Parameters are given for two eases:

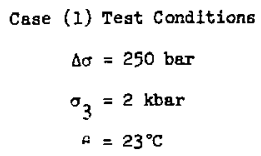

$$
\begin{aligned}
& \text { Parameters for Equation (14) } \\
& \qquad \begin{array}{l}
A_{1}=3.75331 \times 10^{8} \\
\lambda_{1}=0.05935 \\
A_{2}=\lambda_{2}=0
\end{array}
\end{aligned}
$$


Casa (2) Test Conditions

$$
\begin{aligned}
\Delta \sigma & =150 \mathrm{bar} \\
\sigma_{3} & =2 \mathrm{kbar} \\
\theta & =100^{\circ} \mathrm{C}
\end{aligned}
$$

Parameters for Equation (14)

$$
\begin{aligned}
& A_{1}=0.464 \times 10^{7} \\
& \lambda_{1}=0.02904 \\
& A_{2}=0.4084 \times 10^{8} \\
& \lambda_{2}=0.08230
\end{aligned}
$$

where $\Delta o$ is the stress difference (kbar), $\sigma_{3}$ is the confining stress (kbar), and $\dot{k} i$ is the (axial) strain rate $\left(\mathrm{s}^{-1}\right)$. Russell reports that Equation (14), obtained fron constant strain-rate tegts, can be integrated to give the strnin as a furntion of time to simulate a creep test. For the cases above, this yields for

$$
\begin{aligned}
& \text { Case (1) } \varepsilon=1.054 \times 10^{-3} \tau_{T}^{0.2703} \text { and for } \\
& \text { Cese (2) } \varepsilon=7.5 \times 10^{-4} T^{0.35} .
\end{aligned}
$$

Thoras, Char, and Bergeon [35] have analyzed nodel pillar deformations using finite element techniques. In their analysis of a pillar, the load was applied to a pillar and the displacements were computed assuming elastic behavior. f second analysts was then performed assuming creeping viscous flow behavior of the sait to obtain the inelestic (creep) strain rates. The total strain was obtained by audinf the elistic straln to the integrated creep strain rates. In their analyses for the creep deformations Thors et al. cefine a "criep stiffness" rec] as

$$
\begin{gathered}
{[\dot{\varepsilon}]=[c c j \sigma]_{T}} \\
\text { where }[c c]=\frac{1}{E}\left[\begin{array}{cccc}
1 & -\nu & -\nu & 0 \\
& 1 & -v & 0 \\
s y m & & 1 & 0 \\
& & 2(1+\nu)
\end{array}\right] \\
\nu=0.45
\end{gathered}
$$

$$
E=\frac{1}{B\left(J_{2}^{b}\right)\left(\theta^{b} 2\right)\left(r^{b}\right)}
$$


In which $B, b_{1}, b_{2}$, and $b_{3}$ are raterial constants. $J_{2}$ ts the second invariant of the stress deviator ( $\mathrm{ps}^{2}$ ); 0 is the temperature $(K$ ); and $\rightarrow$ is the time (hr). Thons, Char, and Berge. examined the pillar tests of Lomentck [14] and found that the deformation history of the plllars could be matched by selecting the following constants:

$$
\begin{aligned}
& B=25.6 \times 10^{-38,}, \\
& b_{1}=0.974, \\
& b_{2}=9.660, \text { and } \\
& b_{3}=-.750 .
\end{aligned}
$$

For the pillar tests performed by Thoms et 02 . using Weeks Island selt, the parameters ylelding good correlations to the messured plllar deformations are

$$
\begin{aligned}
& B=15.6 \times 10^{-38,}, \\
& b_{1}=0.975, \\
& b_{2}=9.65, \text { and } \\
& b_{3}=-.90 .
\end{aligned}
$$

Henzel et al. 15 ? reported primary creep laws resulting from experiments performeo on sock salt taken from German mines. The empirical equations for prinary creep they reported are power laws of the form

$$
\epsilon\left(\theta_{1}, 0,7\right)=\left[A \exp \left(\frac{\Delta \theta}{\theta_{K}} \cdot \frac{\theta_{1}}{\theta_{0}}\right) \cdot \frac{\mu+1}{\eta}\right]^{\frac{r}{\mu+1}} B\left(\frac{\eta}{\mu+1}\right) \frac{\eta}{\mu+1}
$$

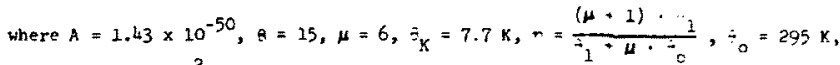
and $J$ is in $\times \mathrm{Fa} / \mathrm{cm}^{2}$.

Ferrish ara Gangi [ [] have vorked on development af a constitutlve model pertaining to the primary regire observea in constant strain-rate experinents. The creep laws they present give stress as a function of tine under condtions of constant strain rate $\mathbf{a s}$

$$
\sigma(\tau)=\sigma_{a}\left(1-\exp \left(\tau / \tau_{0}\right)\right)
$$


where $a$ is the stress and $\tau$ is the time. They have used least squares curve-fitting technlques to evaluate the best values for $\sigma_{B}$ and $\tau_{0}$ for several of Heard's ' 127 constant strain-rate experiments. They have concluded that the data suggests a summation of terms:

$$
\sigma(\tau)=\sigma_{1}\left(1-\exp \left(\tau / \tau_{1}\right)\right)+\sigma_{2}\left(1-\exp \left(\tau / \tau_{2}\right)\right)
$$

They feel that the use of two exponential functions is motivated by the possibility of having more than one deformation mechanism contributing to the creep of the sait. The different mechanfsms would exhibit differe : activation energies and thus would require separate functions to describe their behavior.

Le Comte [13] performed creep experiments on single crystal and artificial nol;crystalline rcci salt over a temperature ramge from 0 to $320 \mathrm{c}$, a confining fressure range to $100 \mathrm{MPa}$ ind stress differences to $13.8 \mathrm{MFa}$. Ie comte concluded that Individual creep curves could be well approximated by

$$
E=A+B T^{n}
$$

where A, B, and $n$ are constants empirically determined from the data, Carter [36? Includes in a report of the petrofabric enalyses of Lyons, Kansas and Jefferson Islard, Louisiana, rock salt a prinary creep representation of Le Conte's [13] data for 1 kbar confining pressure tests over temperatures of 175 to $200 \hat{0}$. This equation is given as

$$
\varepsilon_{t}=200 s^{1.4} \tau^{0.55} \exp \left(-\frac{19.7}{\pi 0 \times 10^{-3}}\right)
$$

where $e_{t}$ represents the transient creep strain, $\sigma$ is the stress (bars), $T$ is the time (s), $\theta$ is the temperature (K), $A$ is the universal gas eonstant, and 19.7 is the value for $E$ (activation energy) (keal/mole).

It should be noted that several investigators have reported constitutive acustions of the general form $\varepsilon=f(T)$ or $\sigma=f(T)$. These eavations apply to specific atress states or strain rates and are not appliceble to general stress and temperature fields.

Primary creep laws presented by verious investigators are stimarized in Table 1 . only those laws that include stress, tenperature, tine (or strain) are included in the 
sunmary. The total accumulated creep strains predicted by some of these equations are presented in Table 2 for several combinations of constant stress, constant temperature, and time. Simple uniaxial stress was gatumed (i.e., $\sigma=\sigma_{1}, \sigma_{2}=\sigma_{3}=0$ ) for computing accumalated creep strains. As can be seen, the computed strains vary widely with some resching values in excess of unity. These variations may be due to the origin of the raterial, to the testing procedure used, or to the extrapolation of stress, temperature, aut time to values used in this comparison that ere beyond the range of parameters considered during testing. Hansen [30] has tabulated a similar comparison of accurmilated strains for primary creep lews resulting from tests on Lyons, Kansas and sG:theajt New Mexico salt. Creep strains vary by more than a factor of two for the different laws within a perlod of two days under conditions of 3000 psj stress difference and $22.5^{\circ} \mathrm{C}$ temperature.

\section{IV.2 Secondary Creep Constitutive Equations and Applications}

Hedley [37] has examined the convergence rates of rooms in 5 different salt minis and used an eouation similar to those used to descrioc isothermal, secondery creep for a description of the results. He develops the eauatioi.

$$
\dot{\varepsilon}=15 \times 10^{-8} x^{2.7}
$$

wite re $\dot{e}$ is the roon convergence rate (in/in/tay $\times 10^{-6}$ ) and $\sigma$ is the pllier stress (psi).

Obert ?20] studied the deromation behaviar of model pillars constructed from salt, trona, ano potash ore. He included primary creep and attempted to fit a model of the form

$$
\varepsilon=\frac{\sigma}{E_{m}}+\frac{\sigma}{3 \eta_{m}} \tau+\frac{\sigma}{E_{k}}\left[1-e^{\frac{-E_{k} \tau}{3 \eta_{k}}}\right]
$$

(where $E_{\pi}, T_{m}, E_{k}$, and $\gamma_{k}$ are material careneters, $J$ is the pillar stress, ard tine) to the observed behavior of the pillars, but found that by using constant parameters the Iinear model could not accurately fit the results. Instead, obert reports thet a power law of the form 


$$
\dot{\varepsilon}=D \sigma^{n}
$$

could accurately describe the steady-state creep obgerved in the constant force piliar tests. For halite obert reports values of $n$ of 3.0 to $3 . \mathrm{L}$ and strain rates for model salt pillers made of Michigan selt and Kansas salt of $1.6 \times 10^{-10}$ and $0.3 \times 10^{-10} \mathrm{~s}^{-1}$ for axial stress levele of 1000 psi and amblent temperature. Obert dic not observe the transition to tertiary creep for strodns up to 25 percent.

Thompson and Ripperger [18] performed experiments on rock salt tiken from Grand Salthe, Texas and from Hockley, Texas. They used a power law of the form

$$
\dot{\varepsilon}=c\left(\frac{\sigma}{a_{0}}\right)^{n}
$$

to model the lsothermal steady-state benavior observed in the experiments. An empirical rit to the data gave the values of $\mathrm{c},{ }_{0}$, and $\mathrm{n}$ as $11.4 \times 10^{-7} \mathrm{~min}^{-1}, 2500$ psi and 5.25, respectively.

Heard [12] has provided creep laws corresponding to the constant strain rate tests performed or annealed 1sotropic aggregates of helite unaer conditions 2 ktar confining pressure, 23 to $400^{\circ} \mathrm{C}$ temperature, and $10^{-1}$ to $10^{-8} \mathrm{~s}^{-1}$ strain rates. In regions of steady-state creep, governed by polygonization by dislocation climb, Weertran's model (Equation (2)) consistently fit the date using mean coerricients defined by

$$
\dot{\varepsilon}=3 \times 10^{-6} \exp \left(23.5 \times 10^{3} / 89\right) \sigma^{5.5}
$$

where $\dot{a}$ is the strain rate $\left(s^{-1}\right)$, $A$ is the temperature $(K)$, o is the differential streas (bar) and $\mathrm{R}$ is the universal gas constant ( $c a i /$ mole $X$ ). At low temperatures and high strain rates, appreciable strain hardening was observei. For high stresses, Heard reports that the deformation mechanism is precominantly slip (dislocation pileup). He reports a creep law of the form

$$
\dot{c}=4.5( \pm 0.7) \exp (-26.0( \pm 2.3) / 2.30 \mathrm{R} 5) \sinh (0 / 46.9(-3.0))
$$

to approximate the salt behavior for this mechanism. Feard provides a transition value for the two models at high stresses as $\dot{\varepsilon} / D \approx 10^{9} \mathrm{~cm}^{-2}$, where $D$ is the diffusivity of the rate-controlling diffusing species. For very low strain rates (on the order of 
$3 \times 10^{-14} \mathrm{~s}^{-1}$ ) Heard suggests that Nabarro-Herring creep would dominate. A linear relationship between stress difference and strain rate of the form

$$
\dot{\varepsilon}=\frac{\mathrm{abD}}{\boldsymbol{L}^{2} \mathrm{R} \theta} \sigma
$$

exists for liabarro-herring creep where

$$
\begin{aligned}
& L=\text { average grain diameter } \\
& \mathbf{a}=\text { constant }(\approx 5) \\
& \mathbf{b}=\text { atomic volume } \\
& \mathbf{R}=\text { universal gas constant }
\end{aligned}
$$

The tronsition from creep described by Weertmen's law (Equation (26)) for polygonizetion to Kabarro-Herring creep is reported uy heard at strain rates defined by $\dot{\varepsilon} / \mathrm{D}=10^{2}$ to $10^{3} \mathrm{~cm}^{-2}$ for halite. Further, he gives a temperature linitation of $\hat{*}>170 \mathrm{C}$ for Nabarro-herring to occur. Heard reports that equivalent viscosities for rock salt range from $10^{18}$ to $5 \times 10^{21}$ poise. Heard points uut that NabarroHerring creep was not observed in his experiments and is not expected to occur under geologic applications.

Heard [38] has annlied these creep laws to the analysis $c$. heated salt pillars at $600-800 \mathrm{~m}$ depth obtaining times that rooras will remain open as

$$
\begin{array}{ll}
2500 \text { to } 1000 \text { years at } 303 \mathrm{~K} \\
220 \text { to } 70 \text { years } & \text { at } 323 \mathrm{~K} \\
1.6 \text { to } 0.3 \text { years } & \text { at } 373 \mathrm{~K}
\end{array}
$$

Where constant stress and temperature were assumed throughout the pillar.

Hansen and Mellegard [1] ] estimated activation energies for salt fron southeast New sexico. They reported that values range from $8450 \mathrm{cal} / \mathrm{mole}$ to $19715 \mathrm{cal} / \mathrm{mcle}$. Phey note that these valies are within the range of values reportec oy Le conte. Hansen and Mellezard also have estimated the coefficieat for the stress power law appearing in secondary creep laws of the form proposec by ieertran , 1 ?. They report that, with the liwited data available, the exponent on stress appears to be on the order of 6 .

Dawson and Tilierson [39] have performed thermamechanicaliy soupled creet anilyses of isothermal and heeted room and p1liar geometries as part of an emplacement alter- 
natives study for WIPP. They used creep duta reported by Wawersik [40] for creep of polycrystalline rock salt from southeastern New Mexico to empirically determine the coefficlents appearing in Weertman's secondary creep model. The equation they used is

$$
\sigma_{\text {II }}^{\prime}=4.33 \times 10^{7} \exp (1773.33 / \theta) \dot{\varepsilon}_{I I}^{2 / 3}
$$

where

$$
\begin{array}{rlrl}
\sigma_{I I}^{\prime} & =\left(\frac{3}{2} \sigma_{i j}^{\prime} \sigma_{1 j}^{\prime}\right)^{\frac{1}{2}}(P E) & & \text { Cauchy Stress Deviator } \\
\dot{\varepsilon}_{I I} & =\left(\frac{2}{3} \dot{\varepsilon}_{1 j} \dot{\varepsilon}_{i j}\right)^{\frac{1}{2}}\left(s^{-1}\right) & & \text { Deformation Rate } \\
\theta & =\text { Temperature }(\mathrm{K}) . &
\end{array}
$$

Dewson and Tillerson predicted closure retes for three design alternetives eack havirfe effective heat $20 a \mathrm{ds}$ of $150 \mathrm{kw} / \mathrm{acre}$. Their anolyses were carried out usire a finite element coie that is besed on a formulation for creeping incorpressiole flox coupled with conductive-convective heat transfer.

TiIlerson and Dawson [4i] have also performed a parameter study for a raom closure simulation in which secondary creep law paremeters, thermal properties, appliea heat load, and assumed boundary conditions have been varied. Specifically, they have exemined nower law exponents for stress in a Weertman's creep law (Equation (2)) of 3 ana 5 anc ectivation energies of 10.4 and $32.9 \mathrm{kas} / \mathrm{mole}$. Cther perameters in Wieertinan's equation were determined enpirically using data reforted by Waversik $\left[\because 0^{\circ}\right.$. The closure rates were significantly affected in both heated and isothernal appli cations.

Munson [7] has developed a preliminary deformation mechanism map (such as proposed by Ashoy [42]) for salt. The deformation mechanism map was constructed with the aid of creep data reported by Poirier [17], Kingery and Montrone [43], Burke et a 1. [0?, Heard [12], and Hansen and Mellegard [11]. He uses the data rrom these sourees to deftne boundarles on the deformation mechanlsm ang that represent the change from one doainant mechanism to another. Nunson discusses four creep mechanisms and indicates 
that there is a fifth, yet undefined, mechanism posaible. The four known mechanisms are defect-less flow, dislocation glide, dialocation climb creep (including pipe and volume modes) and diffugior a: creep (Including coble (grain boundary diffusion) and Nabarro-Herring (volume difrusion)).

Munson has constructed a preliminary constitutive model for rock aalt. The bas1s of the mojel is a secondaiy creep equation that allowg for two corpeting mechanisms, namely the dislocation climb crenp and the widefined mechanism. For dislocation clinb creep a power law dependence in stress is asaumed such that

$$
\dot{\varepsilon}_{B_{1}}=s_{1} \exp \left(-Q_{1} / R \theta\right) \sigma^{n_{1}}
$$

where $\dot{\varepsilon}_{s_{1}}$ is the dislccation climb creep secondary strain rate, $Q_{1}$ is the activation energy for the mechanism, $n_{1}$ defines the stress dependence for creep, $S_{1}$ is a constant, - is the stress, $R$ is the universal gas constert, and $\theta$ is the temperature. For the undeflned rechanism Munson uses a creep law of the form

$$
\dot{\varepsilon}_{s_{2}}=S_{2} \exp \left(-q_{2} / R A\right) f_{2}(\sigma) .
$$

The complete steady-state response is obtained by adding together strain rates defined by the two mechanisms to obtain

$$
\dot{\varepsilon}_{s}=\dot{\varepsilon}_{s_{1}}+\dot{e}_{s_{2}} .
$$

To acconmodate the primary creep regine within the model, funson first essumes that the rolic of primary creep is to supply dislocations that form a sable substructure from which eccondary creep occurs. Further, he assumes that primary creep exhibits the seme activation energies as does secondary creep. This allows Hurson to incorporate a primary regime by modfying the seconotary models as

$$
\dot{E}=F \dot{E}_{S} .
$$

F Is an exponential function that diminishes to zero as the accumulated traysient strain approaches a predetermined value according to the equation

$$
F= \begin{cases}\exp \left(\dot{\Delta}\left(1-\frac{\varepsilon_{t}}{\varepsilon_{t}^{*}}\right)\right) & \varepsilon_{t} \leq \varepsilon_{t}^{*} \\ I & \varepsilon_{t}>\varepsilon_{t}^{*}\end{cases}
$$


where $\dot{\Delta}$ is the transient strain rate change and $s_{t}^{*}$ is the transient strain $11 \mathrm{mit}$.

Wawersik [40] has used an equivalent viscosity

$$
\eta=\frac{\left(\sigma_{1}-a_{3}\right)}{3 \varepsilon_{1}}
$$

to compare with data reported by Ode [44], Heard [12], and others. He fourd thet ruck salt from the 2100 to $2000 \mathrm{ft}$. level of drillhole AEC \#7 yields viscosity values of $10^{13}$ to $10^{17}$ poise for 1000 psi stress difference, 500 psi mean stress and tenperatures ranging from 24 to $130^{\circ} \mathrm{C}$. Extrapalated values reported by other investigators mentioned above ranged from $10^{14}$ to $10^{21}$ poise.

Mraz [45] reports that based on obs-rved underground conditions, rock salt behaves as an elastic-perfectly plastic substance. He indicates that salt exhibits a well defined eiastic limit of 212 psi. Further, Mraz reports an equivalent viscosity for plastic deformations of $2.2 \times 10^{18}$ poise for rock sait consisting of $58.5 \%$ halite, $40.2 \%$ sylvite, $0.5 \%$ carnallite, and $0.8 \%$ clay.

The secondary creep laws reported by the various investigators are sunnarized in Table 3. For each equatiot. the units required for stress, temperature enc $t$ ine fas given in the reference) are listed and the source of sample material is $b$ iven. The secondary ereep rates predicted by each law for several combinations of stress and temperati -e are presented in Table 4. In the se comparisons, a state of luiexial sares: has been assumed so that the axial stress, stress difference, and effective stros: ars. all equal. It should be noted that the activation energics are auite different brtwoss Heard's equation and that of Dawson and Tillerson. Fhis can be attributec to the possiblity that different mechanisms are dominant in the regines where data is obtained for these laws. Extrapalation to the conditions wile re the comparisurs are made leads to the difference in strain rates. This suggists the need to acconst for more than ore mechanism occurring simultaneousiy.

\section{IV.3 Elastaviscoplastic Constitutive Equations and Applications}

Winkel, Gerstle and Ko $\lceil 46]$ have reported on analyses perforned using elastoviscoplastic material models for potash. The bulk behavior was assumed to pe elastic while the deviatoric response was modeled with a cambination of springs, lashpots ant 
sliding elements. The values of material parametera were evaluated from $2-3 / 4$ Inch diameter specimens fabricated from posash ore frcm the Carlsbad area. The octahedral yield stress $\left(\mathrm{k}_{\mathrm{OCr}}\right)$ was expressed as a function of mean stress $\left(\sigma_{\mathrm{m}}\right)$.

$$
k_{\alpha c r}=a+b \exp \left(c \sigma_{m}\right)
$$

where

$$
\begin{aligned}
& a=1145 \mathrm{pst} \\
& b=1000 \mathrm{ps} 1 \\
& c=.00153 \frac{1}{\mathrm{ps} 1}
\end{aligned}
$$

For stress states below jielding, l1near viscoelastic response was assumed for the deviatoric deformations, whlle for stresses above yielding, viscoplastic response was assumed. Winkel et al. Iist the parameters for the New Mexico potash in their paper and compare these to paraceters reported by Serata [47] for a similar materlal model for salt. They used this material model to predict the closure rates of holes drilled into pillars in a potash mine near Moab, Utah. The comparison of predicted values with measured values are glven for the material parameters derived fron Calsbad potash and the parateters from serata's model for salt.

Serata [47] hes published numerous erticles on the analysis of time-dependent deformations of salt cavities and openings. One model for salt uses a yield stress. For stresses below this yleld stress, creep is viscoelastic (recoverathe); whereas, for stresses above the yleld stress, the creep is viscoplastio (permanent). The yieid stress is a function of strain rate and total strain. For zero strain rate at $100^{\circ} \mathrm{C}$ the yleld strength given by Serata is 500 psi. This value increases with increasing strain rate. Serata observes that the transition from viscoelastic to viscoplastic behavior is characterized by Poisson's ratio epproaching 0.5 and by the strain rate changing from a diminishing value with time to a constant value for constant stress. This transition occurs between 700 and 800 psi according to serata. Serate hes also incorporated a loss in the shear strength oue to accumulated strain as a function of mean stress. 
Langer [48] has reported elastoplagtic-creep rheological modela for rook salt. In these models, the total deformation is compused of elastic, inelastic, and creep components as

$$
\varepsilon=\varepsilon_{\mathrm{e}}+\varepsilon_{\mathrm{n}}+\varepsilon_{\mathrm{p}}+\varepsilon_{\mathrm{B}}
$$

where $\varepsilon_{\mathrm{e}}$ is the elastic strain defined by

$$
\varepsilon_{e}=\frac{\sigma}{E_{0}}
$$

$z_{x}$ is the plastic strain defined by

$$
E_{n}=\frac{a}{E_{k}}\left(1-\exp \left(-E_{k} \tau / r_{k}\right)\right),
$$

$\nabla^{\prime}$ is the primary creep ciefined by

$$
\varepsilon_{p}=\left(\sigma-\sigma_{k s}\right) \sum_{i=1}^{\eta} \frac{1}{\bar{E}}\left(1-\exp \left(-\frac{E_{1}}{\eta_{1}} \tau\right)\right),
$$

$\varepsilon_{s}$ is the secondary creep defined by

$$
\varepsilon_{\mathrm{s}}=\left(\sigma-\sigma_{\mathrm{F} L}\right) \frac{\tau}{\eta_{\mathrm{p} \ell}},
$$

where $E_{0}, E_{R}, \eta_{R}, E_{i}, \eta_{i}$ and $\eta_{p}$ are material parameters. For stress states defined by $\sigma<\sigma_{\mathrm{kr}}$ and $\sigma<\sigma_{\mathrm{F} \ell}$ only the elastic and plastic strains are computed. For stress states such that $\sigma>\sigma_{\mathrm{kr}}$ and $\sigma \geq \sigma_{\mathrm{F} \ell}$, both the primary and secondary creep strain components are included in the total. For stress states defined by $\sigma>\sigma_{k x}$ and $\sigma<\sigma_{F \ell}$, only the primary creep component $1 s$ added to the elastic and plastic $\operatorname{co}$ ponents of strain. In place of the constant viscosity described by $\eta_{p}$, , Langer aiso riscusses the use of nonlinear laws with gower law and exponential stress dependience.

\section{4 Creep Fupture KodeIs}

liair and Singh [16] studied creep rupture criteria under isothermal conditions for rock salt using a linear cumulative darage theory. Nair and singh performed triaxial extension tests and observed that induced axial tensile strain causes failure. The stress difference (logarithr) was plotted versus the tine to faijure. This curve is well approximated by a straight Ifne. For mul:laxial states of stress, Nair and 
Singh suggest a substitution of the maximum principal stress difference for the stress that controls the time to failure. 


\section{SUMMARY AND ASSESSMENT}

As outlined in the previcus section, a varlety of primary and secondary creep models have been empirically evaluated to describe the long term behavior of rock salt from laboratory and field igta. Some Investigators have tied the form of their equations to the physical mechanisms controlling creep, while others have simply used curve ritting technigues.

The bulk of the work performed to date has been within the context of primary creep. Prinary creep lows are necensary to describe the short tem creep response of salt and are effective in providing constitutive equations for conputational methods that are applied to analyze relatively ghort term phenomena, However, salt is known to deform in the secondary creep regime for a large portion of its total deformation under a wide ral ge of stress and temperature conditions. Primary creep lews exhibiting monotonically decreasing strain rates as either a function of time or strain become non-conservative (in terms of tine closure) as secondary creep becomes dominant. For time periods extending well beyond the time span of measured data used to formulate the law, littie confidence can be placed in computations based solely on primary ereep laws. This is enjiasized by 5agr, who cites several examples of constant comergence rates abserved in mines. The convergence measurements represent an integrated effect over the pillar height (and include rotion in the floor and ceiling) and, therefore, do not provide conclusive evidence that all of the material is deforming in $\mathrm{e}$ secondary creep rocie. However, the measurements do strongly suggest thet primary creep models are inadequate.

Secondary creep models, on the other hand, are useful for predictions of deformations in which the secondary phase doninates. Secondary creep laws with purameters determined using the deformation rates evaluated at the end of creep tests tend to be conservative over long time periods since the experimentally observed creep rates are usually still decreasing at the end of the creep test. Creep date reported by Nawersik [3] and Hensen and Mellegard [111 represent the data that is most applicable to WIPP analyses since the data is derlved from New Mexico salt tested over appropriate conditions. 
The use of sone elastoviscoplastic models causes difficulty in properiy accounting for the zero (or nearly zero) y1old limit and the inseparable time-dependent and timeIndependent plasticity exhlbited by salt during the initial loading phases. Further, the definition of a unique yield surface is questionable in light of the time-dependent behavior of salt.

The combined work of the investigetors sumbrized herein covers a varlety of constitutive equations for primary creep and secondary creep. All aspects of the creep response of rock salt have not, however, been represented by a single comprehensive constitutive model. Additional data are needed to quantify fully the observed behavior. Among the areas requiring research emphasis are (i) criteria that define the transition from primery to secondary creep or from secondary to tertiary creep and (ii) formulations that account for possible histciry effects on secondary creep rates. 


\section{A PFEND IX A. STRESS AND STRA IN BEASURES}

In most of the work reviewed, the stress and strain measures used were either noorly defined or ingdequate for the implied application. Many reported using engineering stratn, for instance, as defined by

$$
[\varepsilon]=[F]-[I]
$$

where $F$ is the deformation gradient and $I$ is the 1dentity matrix. This strain measure is not objective, and thus will not be invariant to uooriinate rotations. Thus, to apply it to general multiaxial conditions of stress and strain with possibly lerge rotations could lead to appreciable errors. Similarly, the logarithmic strain is not objective and is inapuropriete for large strain and large rotation analyses. strain rates derlved from the engineering or natural strain measures sufier the same inadequacy. However, the deformation rate tensor

$$
d_{i, j}=\frac{1}{2}\left(\dot{u}_{i, j}+\dot{u}_{j, i}\right)
$$

is objective. It can be shown that constant strain rate tests are nat eouivalent tc constant deformation rate tests. Further, usual procedures to convert primary ereep leks from the form $\varepsilon=f(0, \Theta, T)$ to $\dot{\varepsilon}=f(0, \theta, \varepsilon)$ become more complex when large strain measures are used.

Many of the stress measures reported appear to be based on the original geometry of the systen without properly accounting for large strains occurring curing laree deformations (sich as by using the Fiola-Kirchosf stress). The Ceuchy stress, which. properly defines stress during large strain, has been used by some investigators. Not accounting for changes in stress as pillars deform in either laboratory models or aines cas leaj to the interpretation that salt deformations occur all within the primary creep regine when the deformation may be the result of secondary creep.

It is important that equations developed as constitutive models far salt be usable by anyone working in the field. For this to happen, it is necessary that stress and strain measures be well derined and be consistent with the reference configuration specified to describe the system. 
I. Wertmn, I." "Dislocation Climb Theory of Steady-State Creer," Transactions, ASTE $61,681-694$ (1968).

$\therefore$ Carter, N. L. and S. F. Kirty, "Transient Creep and semibrittie Behavior or Covetnlline Rocks," Pure and Applied Physfes, 807-839 (i978).

3. Wawersik, H. R. and D. W. Hanmum, "Interim Summary of Sandla creep Experiments on Rock Selt fron the WIPP "tudy Area, Southeastern New Mexico," SAND-7,-0115 (1979).

1. Wuwersik, k. R., "Erfect of Pressure, Deviator stress, and Temperature on the Trensient Creep of a Rock Salt at Low Confiring Fressure," AGU Trans, , 59, (Abstract) (1976).

5. Pnrrish, $\mathrm{N}$. and $A$. Gangi, "Transtent creep in Rock Salt," $1 / 0 \mathrm{WI} / \mathrm{M}-43 / 9$, June $1078)$.

6. Russell, ت. E., "A Creep fociel for Galt," Fifth International symposium on salt, thanbura, Germany, Nay 29.June i, 1978 .

F. Vunson, D. E., "Preliminary Deformation Mechenism Map for Salt (with Application to HIPF)," SAlD-70. $0076(197)$.

3. Hakersik, W. R, and D. W, Hannun, "Wechanical Eehavior or hew Mrkico Fcek salt in Trisxial Compreseion up to $200^{\circ} \mathrm{C}$," Journal of Geophysical Research, in prrse.

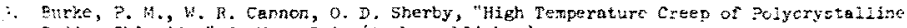
rodium Chloride," J. :lat. Sc1. to be publishec).

1: Carter, $:$. L. and F. C. Hearo, "Temperature arc Pate Depandent Jeformation of ralize;" inericar Jcurnel of Scierce, éç, 193-219:1970).

:. Hansen, I. D. arc K. D. Nellekerd, "Creep Zekevior of Bedded aslt from scutheactern

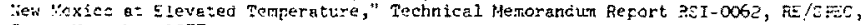
Ine., :ovewter 1977.

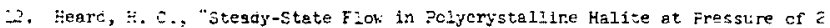
Kilobars," Flow and Frecture of scoks, ed, H. C. Heari, I. Y. Borg, L. L. Carter, and C. B. Raieleh, hmericen Geophys. lnion, p. 201 (1972).

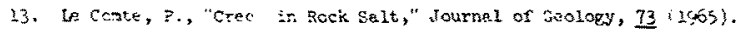

31. Lomerick, T. F., aboratory Pillar "todel Experiments, project salt Vhuit: Lemonsiretion of the Disposa? of Yigh-Activisy Solicified hastes in Unirgrounj

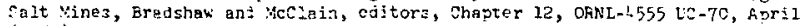
(1)71).

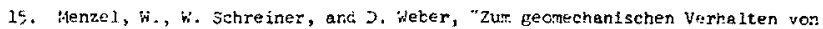
Steinsala bei exhohten Gebiresterparaturen, Hewe Bergbaltechnik, $6 \mathrm{~J}$, Hefth, June ::976;.

16. Neir, K. and R, D. Singh, "Creep Rupture Criteria for Rock 5alt," Fourth sympositam on Salt, Houston, Texas, April 15-12, 1973.

17. Poirier, J, P., "High Temperature Creep of single Crystalline Solum Chloriue I c. II," Fhil. Mag. 26, 701 (1973). 
18. Ihompson, E. G. and E. A. Ripperger, "An Exporimentel Technique for the Invest1gation of the Flow of Halite and Sylvinite," Proceedings of the S1xth Symposiun on Fock Mechanics, University of Missouri at Rolla, October (1661).

19. Dames and Moore Consultants, "Technical Support for GEIS: Radioactlve Waste Isolation in Geologic Formations, Volume 4, Baseline Rock Fropertics-Sult," Y/OWI/TM-36/h, Apri1 (1978).

20. Obert, L., "Deformation Behavjor of Madel Pillars Made from Salt, Trona, and Potash Ore," Proc, VI Symp. Rock Mechenies, U. of Missouri, Rolla (196/4).

21. Carter, N. L., "Steady-State Flow of Rocks," Reviews of' Geophysics and space Pnysies, 14, 301-360, August (1976).

C2. Bear, C. A., Applied Salt-Rook Mechanies 2, Elsevier Scientific Publishing. Company, Amsterdam (1977).

23. Thoris, R. J. and J. D. Martinez, "Preliminary Long-Term Stebility Criterie for Compressed Air Energy Storege Caverns in Salt Domes," prepared for Battelle Pacific Northwest Laboratories, August (1978).

24. MoClain, W. C. and A. M. Starfield, "Analys is of Combined Effects," Project Salt Vault: Demonstration of the Disposal of High-Activity Solidifiei hinstes in Underground S ilt Mines, Bradshaw and Mcilain, editors, Chapter 13, ORNL-4555 UC -70, April (1977).

25. Ieaderman, H., Chapter I in Rheology, Volume II, ed, by F. R. Eirich, Acartemic (1956).

26. Hardy, M. P. and C. $И$. St. John, "Surface Displacements and Plilar Stresses Associated with Nuclear Kaste Disposal in Salt," Nuclear Technology, Auecust b, 1978.

27. Wahi, K. K., D. E. Maxwell, and R. Hofram, "A Two-Dimensionel Simuletion of the The rracrechanical Response of Profect je2t Vaul Including the Excavaticn Sequencing," Science Applications Incorporeted, SAI-FR-8:1-2, Novertber (1971).

28. Haxwell, D. E., K. K. Wahi, and 3. Dial, "The Thermomechanical Pestorse of WIPF Repositories," Science Applications Incorpcrated, SAI-FR-145, octobrr (1)7E).

29. Ratigan, J. L. and G. D. Callahan, "Evaluation of the Predictive Capatility of the Finite Element : Rethod: II. Project Salt Vault--Thermoviscoelastic simulation." $Y /$ owI/SUB-78/22303/11, : Zarch (1978).

30. Hensen, F. D., 'Quasi-Static Stren,th and Creep Defornation Characteristics of Bedded Salt from the Carey Mine liear Lyons, Kansas," Y/OWI/SLE-78/22303/13, June (1978).

31. Hansen, F, D., "Case History Rock Mechanies Exemination of the Jefferson Islanj Salt Mine: II. Laboratory Evaluation of Strength and Creep Deformation Characteristics or Dome Salt Under ConfininE Pressure," Y/Gri /SUB-77/22303/5, June (1978).

32. Hansen, F. D., "Evaluation of an Ineiastic Law for Salt Creep," Energy Rescurces and Excavation Technology, Proc. 19th U, s. Symp. on Rock Mech., Keystone, Colorado, June (1977).

33. Fossum, A. F., "Viscoplastic Behavior During the Excavation Fhas 2 of a 3alt Cavity," Int. Journal for Numerical and Analytical Methads in Geomechanics, I. 45-55 (1977). 
34. Hansen, F. D., "Triexial Quesi-static Compression and Creep Fehavior of Bedde] Salt froin Southeastern New Mexico," Technical Memoranoum Report ASI-0055, prepared for Sandia Laboratories, June (1977).

35. Thoms, R. L., C. V. Char, and W. J. Rergeron, "Finite Element Anelys1z of RockSalt Pillar Ncdels," New Horizons in Rock Nechanics, Proc. 14th Symp. on Bock Mechanics, ASCE, 393-408 (2973).

36. Carter, N. I., "Petrofabric Analyses of the Deformation Bahavior of Lyons, Kansas and Jefferson Island, Loulslana Rock Salt," Y/OWI/sUB-78/22303/9, Decemier (197?).

37. Hedley, D, G. F., "An Appraisal of Convergence Measurenents in Salt Mines," Proc. 4th Rock Mech. Symo., (1967).

38. Hearc, H. C., "Prediction of the Closure Behavior of Terminal Radioactive kaste Storage Vaults in Salt Eodies at Depth," presented at Rockstore, Stocikholm, $\{2978\}$.

39. Dawson, P. R. and J. R. Tillerson, "Comparative Evaluations of the Thermomechs:icel Responses for Three High Level Waste Canister Emplacement Alternatives," sAND 770388, Dec. (1977).

40. Wawersik, W. R., Merro to I. R. Hill, otd Dec. 6, 1976.

41. Tillerson, J. R, and P. R, Dawson, "Heated Room and Fillar Secondary Creeg Response," SAID refort in preparation.

42. Ashoy, H. F., "A Flrst Report on Deformation-Hechanism Maps," Acte Meteliurgice, 20, $887-895(1972)$.

43. Kingery, W. D. and E. D. Montrone, "Diffusional Creep in Polycrystelline Sodium Chloride," J. Applied Phys., 36, 2412 (1965).

44. Ode, H., "Review of Mechanical Properties of Salt Relating to salt Dome Geresis." Geological Soctety of America, Inc., Special paper 88 , (1,68).

45. Hras, D., "Theoreticel Predictions Confirmed by In Situ Rock Eehav1or in Deep Fotash Mine," Proc. 19th U. S. Rock Mech. Symp., U. Nevade Reno, 468-476, May $1-3$ ( 1979 ).

46. Winkel, B. V., K. H. Gerstle, and H. Y. Ko, "Analysis of Time-Dependent Deformations of openings in Salt Media," Int. J. Rock Mech. Min. Sci., 9, 249-260 (1972).

47. Serata, S., "Geonechanical Basis for Design of Underground Salt Cavities," FG:E, 78-FT-59, Energy Technology Conference \& Exhibition, Houston, Texas, Nov. 5-9, $(1978)$.

48. von Langer, $M$. and $H$. Kern, "Temperatur-und belastungsabhangiges Deformations-ver halton von Salgesteinen," Vorhug V Internat. Salz-Symp., Hamburg, (1978). 


\section{ACKNOWLEGEMENTS}

I vant to express appreciation to D. E. Maxwell (SAI), D. Parrish (Texas A E⿱ ⿸) , J. L. Retigan (RE/SFEC), W. R. Wawersile (Sandia) for materials supplied for this review. I also thanis $M$. M. Madsen for her help in preparing the tables. S. Benzley, L. Bcrtholf, W. Brown, B. Butcher, P. Hilton, T. Hunter, R. Krieg, D. Munson, ¿. Seully, J. Tillerson, W. Wawersik, F. Waylend, and W. Wowak provided useful soments during review of this report. 
TABLE 1 FRTMARY CRELP CONST MTUTIVE EQLATIONS

\begin{tabular}{|c|c|c|c|c|}
\hline $\begin{array}{l}\text { Equation } \\
\text { Number }\end{array}$ & Investigajor & Primary Creep Lat & $(3, \tau, 0)$ & Data Source \\
\hline 5 & $\begin{array}{l}\text { Meclain and } \\
\text { Starfield }\end{array}$ & $\varepsilon=1.3 \times 10^{-37} \theta^{9.5} T^{0.3} \sigma^{3.0}$ & K, hours, psi & $\begin{array}{l}\text { Lomenicis's pillar } \\
\text { studies }\end{array}$ \\
\hline 6 & $\begin{array}{l}\text { Meclain and } \\
\text { Starfield }\end{array}$ & $\varepsilon=6.5 \times 10^{-37}, 9.5 \tau^{0.37} 3.0$ & $K$, hours, psi & $\begin{array}{l}\text { Project salt } \\
\text { Vault }\end{array}$ \\
\hline 7 & $\begin{array}{l}\text { Maxwell, } \\
\text { Wahi, and } \\
\text { Dial }\end{array}$ & $\dot{\varepsilon}_{c}=.4656\left[\left(3.1386 \times 10^{-20}\right) \mathrm{s}^{3.0} \exp \left(\frac{-4100}{\theta}\right)\right]^{\frac{1}{.4656}}\left(\varepsilon_{c}^{\frac{1}{.4656}-1}\right)$ & $K, s, P a$ & SENM Salt \\
\hline 9 & $\begin{array}{l}\text { Ratigan and } \\
\text { Callehen }\end{array}$ & $\varepsilon_{i j}=6.87 \times 10^{-15}\left(\frac{\theta}{295.5}\right)^{9.5}{ }_{T}^{0.40}{ }_{J_{2} \sigma_{i j}}$ & $K, 8$, psi & $\begin{array}{l}\text { Project salt } \\
\text { Vault }\end{array}$ \\
\hline 13 & Hensen & $\varepsilon_{1}=1.1 \times 10^{-35} \tau^{0.4656} \sigma^{2.475}, 8.969$ & $k, s, p s i$ & SENA Salt \\
\hline 17 & $\begin{array}{l}\text { Thoms, char, } \\
\text { Bergeron }\end{array}$ & $\epsilon_{i j}=\frac{1.450_{i j}-.45 \delta_{i j}{ }^{0 K K / 3}}{15.6 \times 10^{-38}\left(J_{2}\right)^{.974} 9.65_{\tau}-.75}$ & $K, h_{r}, p s i$ & Weeks Island Salt \\
\hline 21 & Carter & $\epsilon_{t}=200 \sigma^{1.4} \tau^{0.55} \exp \left(\frac{-19.7}{\operatorname{Rg} \times 10^{-3}}\right)$ & $K, \quad s$, bar & Lecante data \\
\hline
\end{tabular}




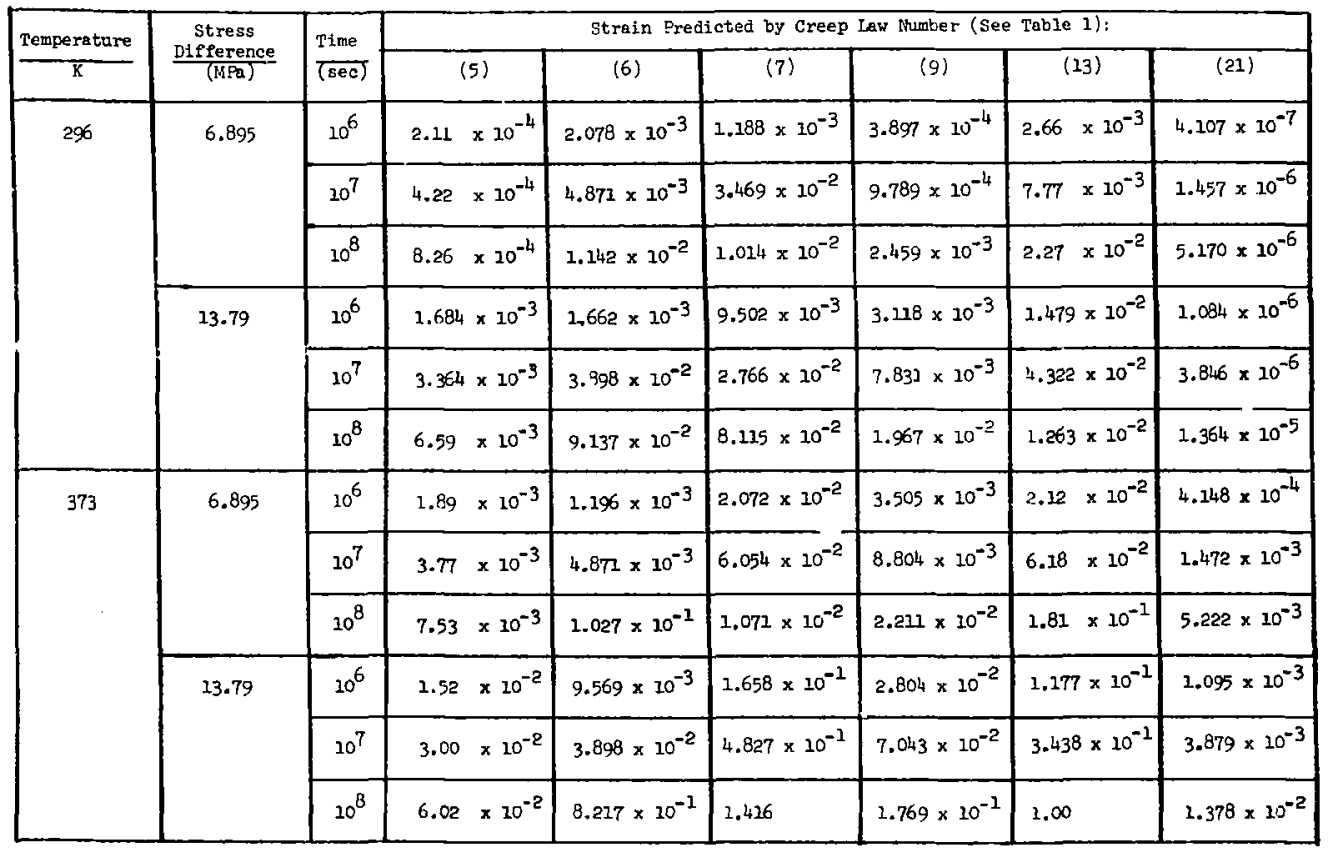


TABLE 3 SECONDARY CREEP CONSTITUTIVE EQUATIONS

\begin{tabular}{|c|c|c|c|}
\hline Investigators & $\begin{array}{l}\text { Secondary } \\
\text { Creep Law }\end{array}$ & Units (strese, temperature, time) & Data Source \\
\hline Hedley (37) & $\dot{\varepsilon}_{\mathrm{A}}=15 \times 10^{-14} 0_{0}^{2.7}$ & psi, -, days & $\begin{array}{l}\text { Salt Mine Convergence } \\
\text { Measurements }\end{array}$ \\
\hline Obert (20) & $\dot{E}_{A}=D 0_{0}^{3.0}$ & Coefficient $D$ not given & $\begin{array}{l}\text { Michlgan Salt } \\
\text { Kansas Salt }\end{array}$ \\
\hline $\begin{array}{l}\text { Thunpson \& } \\
\text { Pipperger (18) }\end{array}$ & $\dot{E}=12.4 \times 10^{-7}\left(\frac{\Delta 0}{2500}\right)^{5.5}$ & psi, -, minutes & $\begin{array}{l}\text { Grand Saline and } \\
\text { Hockley Texas Salt }\end{array}$ \\
\hline Heard (12) & $\dot{\varepsilon}=3 \times 10^{-6} \exp \left(-\frac{11833}{)}\right)(10)^{5.5}$ & bar, $k$, seconds & $\begin{array}{l}\text { Artifically annealed } \\
\text { salt aggregetes }\end{array}$ \\
\hline $\begin{array}{l}\text { Dewson \& } \\
\text { Tillerson (39) }\end{array}$ & $e_{\pi}^{\prime}=1.232 \times 10^{-23} \exp \left(-\frac{5200}{3}\right) a_{\pi}^{\prime} 3.0$ & $\mathrm{~Pa}, \mathrm{~K}$, seconds & SENM SeIt \\
\hline
\end{tabular}

$\sigma_{0}$ - average pillar stress

$\dot{\alpha}$ - stress difference

$\sigma_{\mathrm{I}}$ - effective deviatoric stress
$\dot{\varepsilon}_{A}-$ axial strain rate

$\dot{\varepsilon}$ - stratn rate

$\dot{\varepsilon}_{\Pi}$ - effective deformation rate 
TABIE 4 SECONDARY CREEP RATES

\begin{tabular}{|c|c|c|c|c|c|c|}
\hline Tenperature & $\begin{array}{c}\text { Stress } \\
\text { Difference }\end{array}$ & $\begin{array}{l}\text { Equation (22) } \\
\text { (Yied] ey) }\end{array}$ & $\begin{array}{l}\text { Equetion }(24) \\
\text { (Obert })\end{array}$ & $\begin{array}{l}\text { Enuation (25) } \\
\text { (Thompson \& } \\
\text { Ripperger) }\end{array}$ & $\begin{array}{l}\text { Equation }(26) \\
\text { (Heerd) }\end{array}$ & $\begin{array}{c}\text { Equotion (29) } \\
\text { 'Dewson \& } \\
\text { Tillerson) }\end{array}$ \\
\hline \multirow{2}{*}{$296 \mathrm{~K}$} & $6.895 \mathrm{MPg}$ & $2.13 \times 10^{-10} \mathrm{~s}^{-1}$ & $0.3-1.0 \times 10^{-10} \mathrm{~s}^{-1^{+}}$ & $1.23 \times 10^{-10} \mathrm{~g}^{-1}$ & $1.57 \times 10^{-13} \mathrm{~s}^{-1}$ & $.95 \times 10^{-10} \mathrm{~s}^{-1}$ \\
\hline & $13.79 \mathrm{MFB}$ & $1.42 \times 10^{-9} \mathrm{~s}^{-1}$ & $t$ & $5.57 \times 10^{-9} 8^{-1}$ & $.72 \times 10^{-11} \mathrm{~s}^{-1}$ & $.76 \times 10^{-9} 8^{-1}$ \\
\hline $373 \mathrm{k}$ & $13.79 \mathrm{MPs}$ & * & * & * & $.977 \times 10^{-7} \mathrm{~g}^{-1}$ & $.285 \times 10^{-7} \mathrm{~s}^{-1}$ \\
\hline \multirow{2}{*}{$473 \mathrm{~K}$} & $6.895 \mathrm{MPa}$ & * & * & * & $.492 \times 10^{-6} \mathrm{~s}^{-1}$ & $.677 \times 10^{-7} \mathrm{~s}^{-1}$ \\
\hline & $13.79 \mathrm{MPa}$ & * & * & * & $.222 \times 10^{-4} \mathrm{~B}^{-1}$ & $.543 \times 10^{-6} \mathrm{~B}^{-1}$ \\
\hline
\end{tabular}

* Isotherral Laws

+ Rates $L$ ven explicitly in references

+ Retes not given in reference 